\title{
PLASMA-ASSISTED ADVANCED OXIDATION PROCESS AND NOVEL MATERIALS FOR WATER AND WASTEWATER TREATMENT
}

\author{
${ }^{1 *}$ M. Skiba, ${ }^{1}$ O. Pivovarov \\ ${ }^{1}$ Department of Technology of Inorganic Substances and Ecology, Ukrainian State University of \\ Chemical Technology, Dnipro, 49040, Ukraine.
}

*Corresponding author: margaritaskiba88@gmail.com

\begin{abstract}
The rapid growth in world population brings with it the need for improvement in the current technology for water purification, in order to provide adequate potable water to everyone. The plasma-based advanced oxidation process (AOP) is one of the most widely studied and best developed processes owing to its environmental compatibility, simple structure, efficiencies and ease of operation. In this study, a plasma-based AOP was stably generated using contact nonequilibrium low-temperature plasma and plasma synthesized composite nanomaterials $\left(\mathrm{TiO}_{2} / \mathrm{Ag}\right.$ NPs) for water and wastewater purification. The degradation efficiency of the pollutants was determined by UV-Vis absorption spectroscopy. It was found that, due to the simultaneous production of highly reactive species, plasmas can efficiently eliminate pollutants that are difficult to remove using conventional methods. Aqueous solutions of various pollutants were treated by a low-pressure discharge. Experimental results indicated that CNP was effective for degradation azo dye pollutants (methylene blue (MB) and methyl orange MO) and antibiotics (ofloxacin (OFX) and ciprofloxacin (CFX)): $\mathrm{MB}$ and MO were degraded by $98.5 \%$ and $97.0 \%$, respectively after 3 min of plasma treatment; OFX and CFX were degraded by $\sim 95.0 \%$ and $80.0 \%$, respectively AOP by CNP indicated. The photodegradation of methylene blue catalyzed by plasma synthesized $\mathrm{TiO}_{2} / \mathrm{Ag}$ was studied under UV irradiation. The degradation ( 91\%) was obtained with $2.4 \mathrm{~g} / \mathrm{L} \mathrm{TiO} / \mathrm{Ag}$ within 90 min irradiation.
\end{abstract}

Key words: Advanced oxidation approaches, plasma liqude discharge, wastewater treatment, azo dye, antibiotics

\section{Introduction}

Due to industrialization and population growth, water shortage has emerged as a critical global issue (Boretti and Rosa, 2019). A novel advanced treatment method is needed to destroy different types of pollutants in water and wastewater. Considerable attention has been paid to so- 
called advanced oxidation processes (AOPs), based on in situ generation of strong oxygen-based oxidizers, especially hydroxyl radical, which is among the strongest oxidizers and reacts nonselectively with various types of pollutants (Garrido-Cardenas et al., 2020; Dontsova et al., 2020). Of the many AOPs, a different type of atmospheric cold plasma has emerged as a novel AOP technology because of its efficient degradation efficiencies and environmental compatibility (Foster et al., 2018). ACP is composed of several excited atomic, molecular, ionic, and radical species, coexisting with numerous reactive species, including electrons, positive and negative ions, free radicals, gas atoms, molecules in the ground or excited state, UV light, shockwave and pyrolysis, which contribute to chemical and physical effects that can have an impact on organic pollutants decomposing them into more environmentally friendly compounds (Rancev et al., 2019; Ceriani et al., 2018; Wang and $\mathrm{Xu}, 2012$ ). Different articles reported the treatment of methylene blue (MB), methyl orange (MO), and Congo red dye using different type plasma discharge: non-thermal direct (Attri et al., 2016), indirect atmospheric pressure plasma jets (Ma et al., 2021; Yehia et al., 2020), gas-liquid pulsed discharge plasma (Sun et al., 2012) ect. The degradation efficiency was approximately 80-90\% when the dyes were exposed to plasma for 20-30 $\mathrm{min}$.

Among ACP, contact non-equilibrium low-temperature plasma (CNP) is a promising option from the point of view of practical application (Skiba et al., 2019). Plasma discharge generated between the electrode in the gaseous phase and solutions $\mathrm{AgNO}_{3}$ is a rich source of high-energy electrons $\left(\mathrm{e}_{\mathrm{g}}{ }^{-}\right)$that bombard the solution surface. After thermalization (energy loss through multibody interactions with water molecules) of the $\mathrm{e}_{\mathrm{g}}^{-}$from the gas phase, solvated electrons $\left(\mathrm{e}_{\mathrm{aq}}{ }^{-}\right)$ are formed in the liquid phase. Redox reactions mediated by the $\mathrm{e}_{\mathrm{aq}}{ }^{-}$and other reactive species, such as hydrogen radicals $(\mathrm{H})$, hydrogen peroxide $\left(\mathrm{H}_{2} \mathrm{O}_{2}\right)$, singlet oxygen $(\mathrm{O})$ and hydroxyls $(\mathrm{OH})$.

Moreover. number of articles found related to the application of nanoparticles of noble metals and composite materials $\left(\mathrm{MeO}_{\mathrm{x}} / \mathrm{Ag}, \mathrm{Au}, \mathrm{Pt}, \mathrm{Cu}\right)$ in the advanced oxidation processes (AOP's) for waste water treatment (Wang et al., 2018). In previous publication Ag doped $\mathrm{TiO}_{2}$ composite were obtained by impregnation of the commercial powder $\mathrm{TiO}_{2}$ by plasma-chemically synthesized silver nanoparticles (Skiba et al., 2020).

The main goal is to investigate different type AOP, such contact non-equilibrium lowtemperature plasma and plasma synthesized composite nanomaterials $\left(\mathrm{TiO}_{2}\right.$ decorated $\left.\mathrm{Ag} \mathrm{NPs}\right)$ for water and wastewater treatment.

\section{Materials and Methods}

AOP using contact non-equilibrium low-temperature plasma

The plasma reactor used in this study is depicted in Figure 1. Cathode (diameter $4 \mathrm{~mm}, 18 \mathrm{H} 10 \mathrm{~T}$ stainless steel electrodes) was located in the liquid part, with the anode (diameter $2.4 \mathrm{~mm}$ ) placed at 
the distance of $10 \mathrm{~mm}$ from the surface of solution. Volume of solution in the reactor was equal to $70 \mathrm{~mL}$. Cooling of reaction mixture was ensured by continuous circulation of cold water. Pressure in the reactor was maintained at $80 \pm 4 \mathrm{kPa}$. The voltage of $500-1000 \mathrm{~V}$ was applied to the electrodes to obtain the plasma discharge. The current strength was maintained at the level of $120 \pm 6 \mathrm{~mA}$.

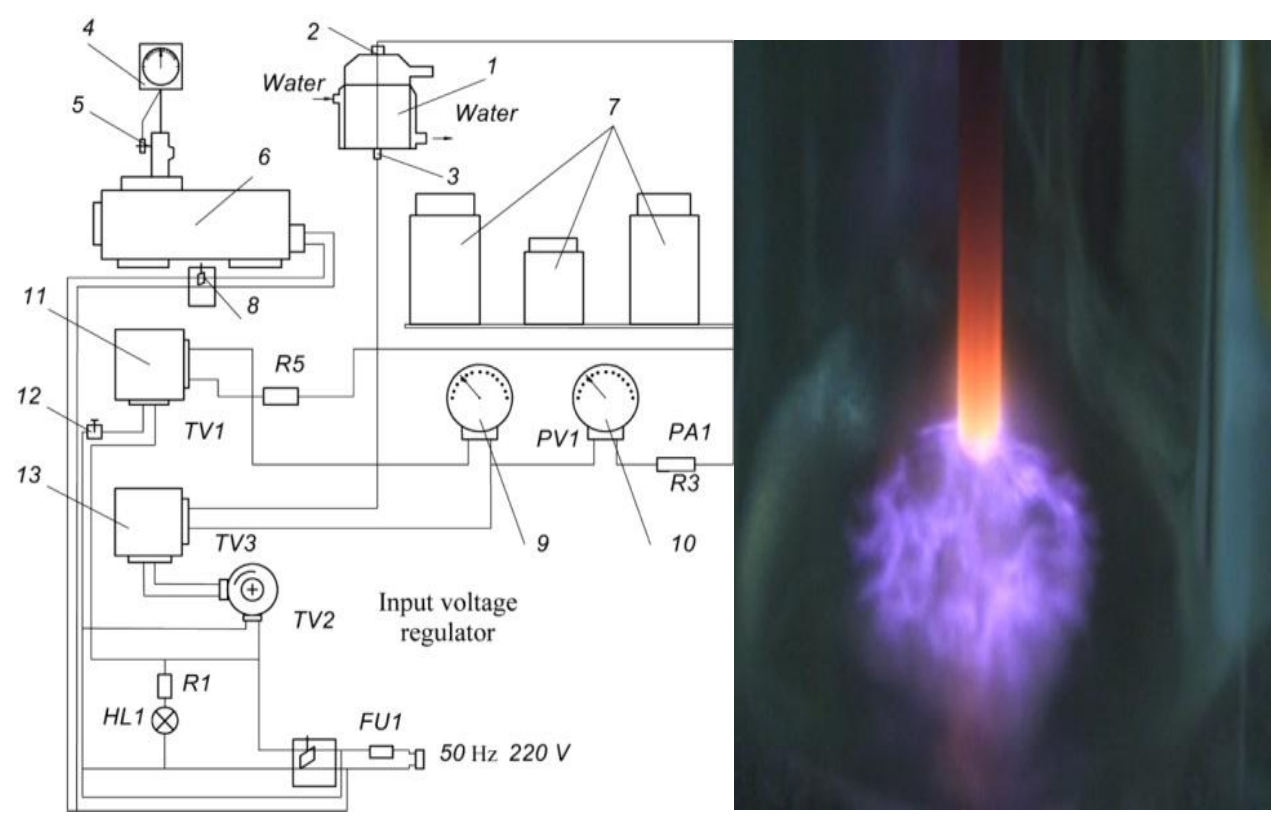

Figure 1. The circuit diagram and photo discharge of the installation for plasma-chemical treatment of water solutions: 1 - reactor; 2, 3 - electrodes; 4 - vacuum gauge; 5 - crane; 6 - pump; 7 - filtering elements; 8 - switch; 9 - voltmeter; 10 - ammeter; 11 - firearm transformer; 12 - switch; 13 - voltage transformer.

Aqueous samples with different pollutants were exposed to CNP and the degradation efficiency was determined by absorbance spectroscopy. Spectra of solutions were obtained by means of spectrophotometer UV-5800PC using quartz cuvettes in the wavelength range of 190-700 nm (FRU, China).

In typical experiment, we selected solutions of MB (methylene blue trihydrate and MO (methyl orange,) which are representative cationic thiazine and azo dyes, respectively, as our targets. The $\mathrm{MO}$ and MB aqueous solutions were prepared by dissolving $10 \mathrm{mg} / \mathrm{L}$ of tap water. Then, $500 \mathrm{~mL}$ of each prepared solution was injected into reactor for the experiments. Continuous degradation of MB and MO in the solutions is indicated by a decrease in the MB and MO concentrations, which was visually confirmed by decolorization. Antibiotics, such as ofloxacin (OFX) and ciprofloxacin (CFX) was investigation too. OFX and CFX in at initial concentration of $10 \mathrm{mg} / \mathrm{L}$.

AOP using plasma synthesized composite nanomaterials $\left(\mathrm{TiO}_{2} / \mathrm{Ag} \mathrm{NPs}\right)$

Ag doped $\mathrm{TiO}_{2}$ composite were obtained by impregnation of the commercial powder $\mathrm{TiO}_{2}$ by plasmachemically synthesized silver nanoparticles (2\% mas). Trisodium citrate was used as capping agent for Ag nanoparticles. The photocatalytic activities of the samples were evaluated by investigating the kinetics of the degradation reactions of the pollutants (MB) in an aqueous 
suspension under irradiation. All the experiments were repeated three times to verify the consistency. The photocatalytic performance of $\mathrm{Ag} / \mathrm{TiO}_{2}$ samples was evaluated through the degradation of MB solution (5-10 mg/L) with irradiation via a $18 \mathrm{~W}$ UV Lamp (365 nm). The intensity of the light was $18 \mathrm{~W}\left(0.034 \mathrm{~W} / \mathrm{cm}^{2}\right)$. The photoreactor was filled with $50 \mathrm{ml}$ of $2.5-10.0$ $\mathrm{mg} / \mathrm{L}$ of $\mathrm{MB}$ and $2.4-7.2 \mathrm{~g} / \mathrm{L}$ of $\mathrm{TiO}_{2} / \mathrm{Ag}$. All reactants in the vessel were stirred using a sheiker to ensure that the catalyst was uniformly distributed during the course of the reaction. Before irradiation, to form an adsorption-desorption equilibrium, the mix was stirred in the dark for 30 min. Total of $3 \mathrm{~mL}$ of solution was sampled at set time intervals and centrifuged to remove the catalyst particles. The intensity of the absorption peaks of $\mathrm{MB}$ at $\Lambda_{\max }=663 \mathrm{~nm}$ was measured with a UV-Vis spectrophotometer and used to track its concentration.

The percent degradation (\%) has been calculated using eq. (1),

$$
\text { \%degradation }=\left(\left(\mathrm{A}_{0}-\mathrm{A}_{\mathrm{t}}\right) / \mathrm{A}_{0}\right) \times 100
$$

where $A_{0}$ is the initial absorbance and At is the absorbance of the sample irradiated for $t$ minutes.

\section{Results and discussion}

AOP using contact non-equilibrium low-temperature plasma

It has been established that the plasma-chemical method is an effective method for water and wastewater treatment. It is shown that in the process of plasmochemical influencing liquid the accumulating peroxide compounds takes place and metals ions are extracted as practically insoluble compounds.

In this part of study, we treated dye solutions under optimized operating conditions and analyzed the absorbance of MB and MO solutions using UV-Vis to measure the degradation and changes in concentration. Because the concentration was directly proportional to the absorbance measured, the change in concentration was obtained indirectly according to the change in absorbance at a specific wavelength (Yamada et al., 2020).

Fig 2 (a) and (b) show changes in the degradation spectra of MB, MO collected and OFX, CFX at various times during the plasma treatment. During the dye treatment using plasma, the concentrations of MB and MO decreased due to chemical oxidation. Continuous degradation of MB and MO in the solutions is indicated by a decrease in the MB and MO concentrations, which was visually confirmed by decolorization. As shown in Fig. 2 (a) $98.5 \%$ and $97.0 \%$ degradation of the MB and MO dyes was observed after 2 min of plasma treatment, respectively. Both the MB and MO solutions were determined to decrease by drawing an exponential graph. As shown in Fig. 2 (b) the degradation efficiency of CFX and OFX in water was $80 \%$ and $95 \%$, respectively. 

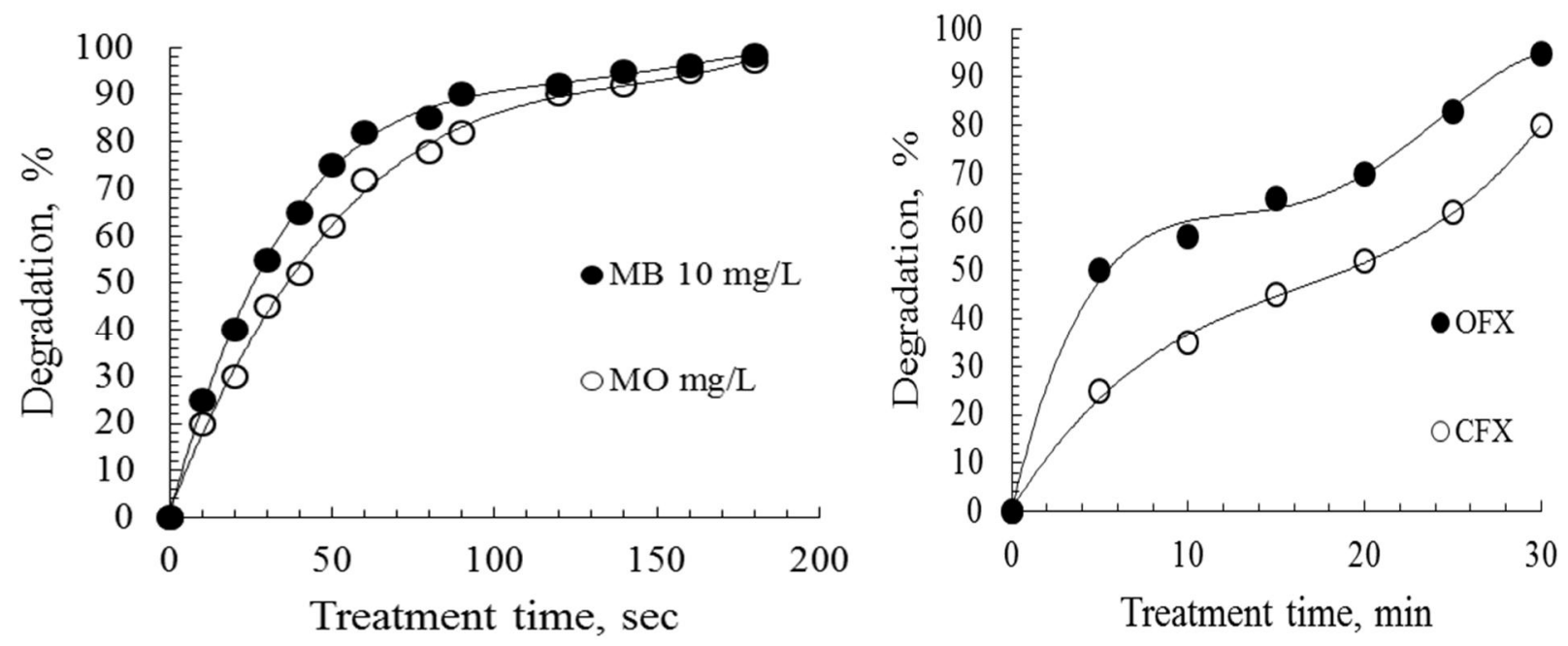

Figure 2. Degradation percentages obtained by UV-vis spectroscopy for MB, MO (a) and OFX, CFX (b) after treatment with CNP.

CNP system has been investigated for the removal of various organic pollutants (phenol, pesticides, pharmaceutical substances ect.) from water (Table 1). It has been established that using the optimal operating conditions a phenol degradation equal to $88 \%$ after only 7-10 minutes of treatment was obtained, while the complete degradation and mineralization has been reached after 18-20 minutes. The degradation efficacy of pesticides after $10 \mathrm{~min}$ of plasma treatment were found to be $88.98 \pm 0.91 \%$ for dichlorvos, $72.52 \pm 0.02 \%$ for malathion and $6.78 \pm 0.47 \%$ for endosulfan. It was found, after only 5 minutes of treatment time, the paracetamol degradation was equal to 93$37 \%$.

Dye degradation was studied using various plasma devices, and energy efficiency was compared according to plasma devices and treatment targets, as shown in Table 2.

Table 1. Percentage removal efficiencies ( $\mathrm{y}$ ) of pollutants after plasma treatment

\begin{tabular}{|c|c|c|c|}
\hline Pollutant & $\begin{array}{c}\text { Concentration } \\
(\mathrm{mg} / \mathrm{L})\end{array}$ & $\begin{array}{c}\text { Treatment time } \\
(\mathrm{min})\end{array}$ & $\begin{array}{c}\text { Removal } \\
\text { efficiency (\%) }\end{array}$ \\
\hline $\begin{array}{c}\text { Phenol } \\
\text { (2-chlorophenol, 4- } \\
\text { chlorophenol and 2,6- } \\
\text { dichlorophenol) }\end{array}$ & $100-300$ & $18-20$ & $98.4-100$ \\
\hline Dichlorvos & 2.0 & $18-20$ & $99.4-100$ \\
\hline Malathion & 2.0 & $15-20$ & $99.4-100$ \\
\hline $\begin{array}{c}\text { b-lactam antibiotics } \\
\text { (amoxicillin, oxacillin, } \\
\text { ampicillin) }\end{array}$ & 100 & $7-15$ & $98.0-99.0$ \\
\hline
\end{tabular}


Table 2. Comparison of energy efficiency for treating organic contaminants in solution using various plasma sources.

\begin{tabular}{|c|c|c|c|c|}
\hline $\begin{array}{l}\text { Type of the } \\
\text { plasma for } \\
\text { treatment }\end{array}$ & $\begin{array}{l}\text { Treated organic } \\
\text { contamination }\end{array}$ & Conditions & $\begin{array}{l}\text { Energy } \\
\text { efficiency } \\
(\mathrm{g} / \mathrm{kWh})\end{array}$ & Reference \\
\hline $\mathrm{CNP}$ & $\begin{array}{l}\text { Methylene blue } \\
\text { Methyl orange } \\
\text { OFX, CFX }\end{array}$ & $\begin{array}{l}\mathrm{t}: 3 \mathrm{~min}, \\
\mathrm{C}_{0}: 10 \mathrm{mg} / \mathrm{L}, \\
\mathrm{V}: 0.5 \mathrm{~L}\end{array}$ & $\begin{array}{l}1.5 \\
(\mathrm{R}: 98.5)\end{array}$ & This study \\
\hline $\begin{array}{l}\text { Multi-hole } \\
\text { DBD }\end{array}$ & $\begin{array}{l}\text { Methylene blue } \\
\text { Methyl orange }\end{array}$ & $\begin{array}{l}\mathrm{t}: 3 \mathrm{~min}, \\
\mathrm{C}_{0}: 10 \mathrm{mg} / \mathrm{L}, \\
\mathrm{V}: 1 \mathrm{~L}\end{array}$ & $\begin{array}{l}3.575 \\
(\mathrm{R}: 98.3) \\
3.506 \\
(\mathrm{R}: 96.6)\end{array}$ & Ma et al., 2021 \\
\hline $\begin{array}{l}\text { Non-thermal } \\
\text { plasma jet }\end{array}$ & $\begin{array}{l}\text { Methylene blue } \\
\text { Methyl orange } \\
\text { Congo red }\end{array}$ & $\begin{array}{l}\mathrm{t}: 30 \mathrm{~min}, \\
\mathrm{C}_{0}: 200 \mathrm{mg} / \mathrm{L}, \\
\mathrm{V}: 0.1 \mathrm{~L}\end{array}$ & $\begin{array}{l}3.4 \text { (R: 97) } \\
3.6 \text { (R: 99) } \\
3.3 \text { (R: 90) }\end{array}$ & Attri et al., 2016 \\
\hline $\begin{array}{l}\text { Pulsed corona } \\
\text { discharge }\end{array}$ & Reactive blue 19 dye & $\begin{array}{l}\mathrm{t}: 10 \mathrm{~min}, \\
\mathrm{C}_{0}: 50 \mathrm{mg} / \mathrm{L}, \\
\mathrm{V}: 1 \mathrm{~L}\end{array}$ & $\begin{array}{l}2.45 \\
\text { (R: } 50)\end{array}$ & $\begin{array}{l}\text { Rancev et al., } \\
2019\end{array}$ \\
\hline $\begin{array}{l}\text { Gas-liquid } \\
\text { pulsed } \\
\text { discharge }\end{array}$ & Methyl orange & $\begin{array}{l}\mathrm{t}: 5 \mathrm{~min}, \\
\mathrm{C}_{0}: 10 \mathrm{mg} / \mathrm{L}, \\
\mathrm{V}: 0.45 \mathrm{~L}\end{array}$ & $\begin{array}{l}0.45 \\
(\mathrm{R}: 50)\end{array}$ & Sun et al., 2012 \\
\hline
\end{tabular}

It was confirmed that the plasma type for processing organic pollutants in the solution is a plasma type generated in the solution and ander. Although the plasma method, operating conditions, and target materials were different, it was confirmed that the developed CNP shows good results.

AOP using plasma synthesized composite nanomaterials $\left(\mathrm{TiO}_{2} / \mathrm{Ag} \mathrm{NPs}\right)$.

Fig. 3 show spectra of $\mathrm{MB}$ depending time irradiation at present photocatalysis $\mathrm{TiO}_{2} / \mathrm{Ag}$ at different MB concentration (2.5-10 mg/L) and fixed amount photocatalist (2.4 g/L).

Two major absorbance peaks of methylene blue were located at 292 and $664 \mathrm{~nm}$, due to benzene ring and heteropolyaromatic linkage (Tichonovas et al., 2013). In addition, the aqueous solution of MB molecules exhibited a double-peak feature at 664 and $615 \mathrm{~nm}$, which correspond to monomers and dimers, respectively. The decrease in absorption at 264, 292, and $664 \mathrm{~nm}$ is due to the destruction of benzene rings and the heteropolyaromatic linkage. The disappearing peaks in the UV-spectra indicate a degradation of the dye molecules. 


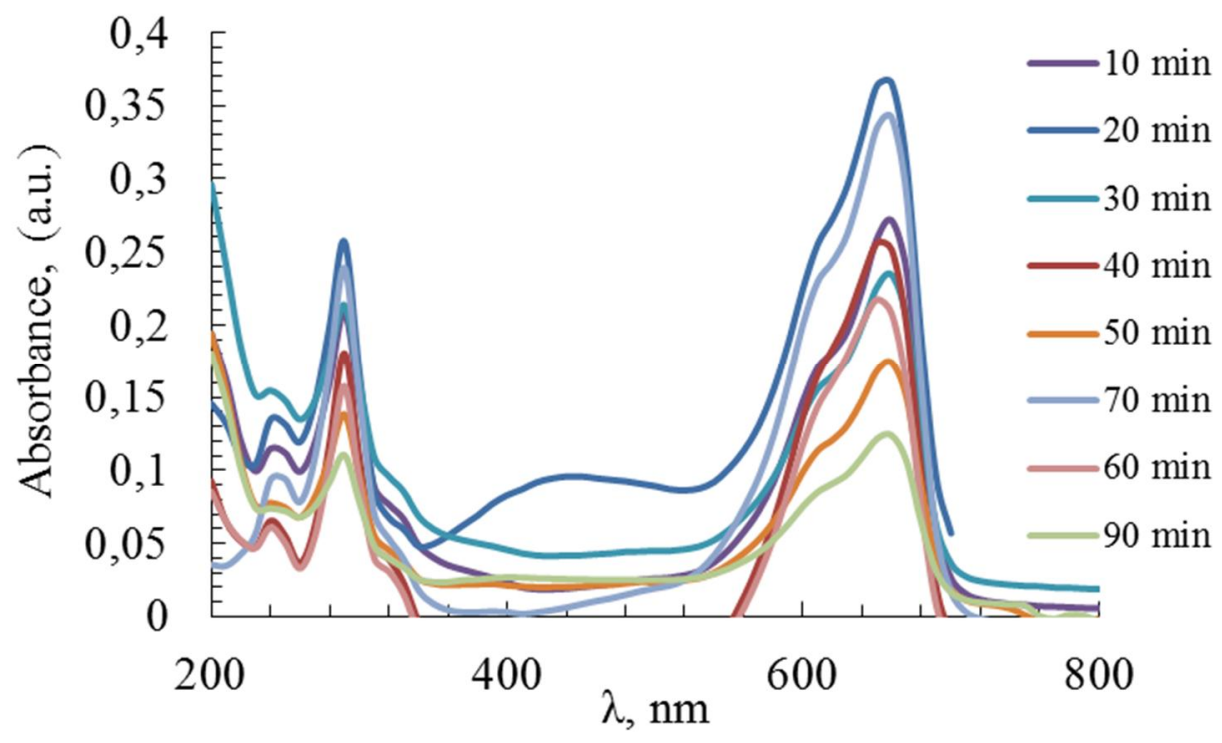

a)

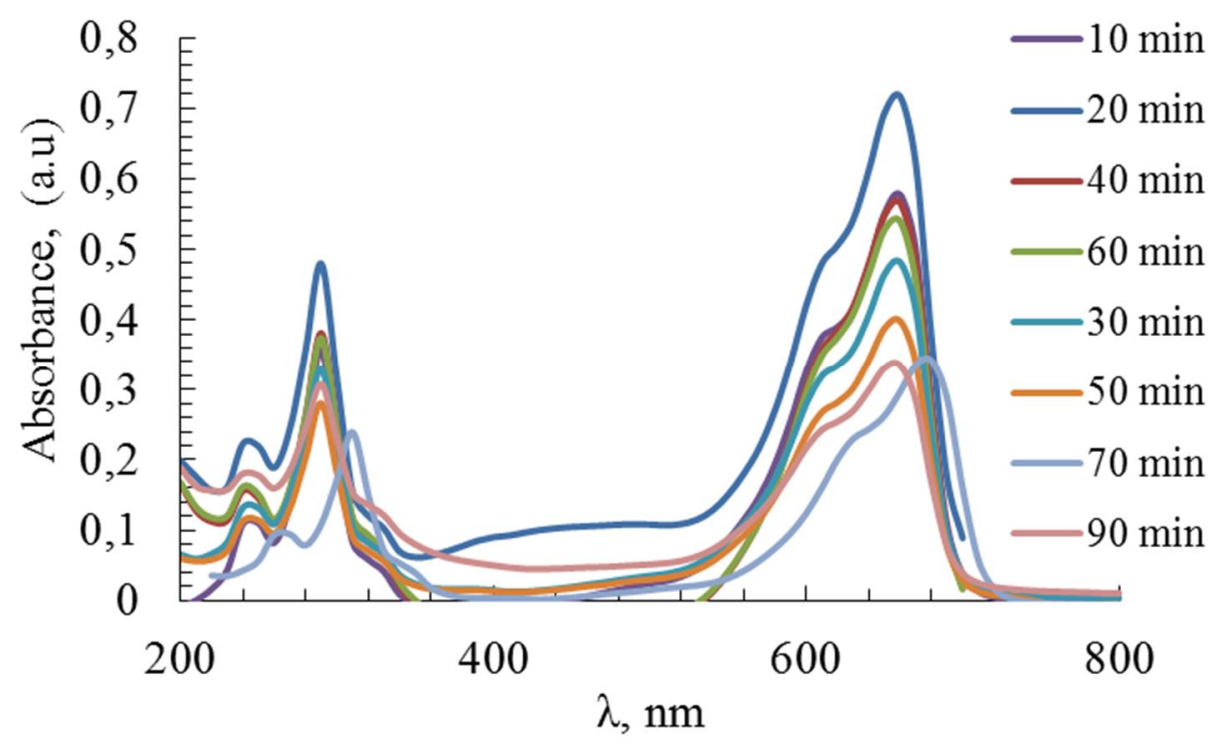

b)

Figure 3. UV-vis spectra of $\mathrm{MB}$ depending time irradiation at present photocatalysis $\mathrm{TiO}_{2} / \mathrm{Ag}$ at different $\mathrm{MB}$ concentration (a) $5 \mathrm{mg} / \mathrm{L}$ and (a) $10 \mathrm{mg} / \mathrm{L}$ at fixed amount photocatalist.

Figure 4 shows the effect of initial concentration of MB $(2.5-10 \mathrm{mg} / \mathrm{L})$ on the degradation. The rate of degradation decreased with an increase in the initial MB concentration. Two factors are responsible for the decrease in degradation efficiency with an increase in the initial dye concentration: an increase in the number of dye molecules adsorbed on the surface of the catalyst leads to a decrease in the number of active sites that generate hydroxyl radicals; an increase in the light absorbed by the dye molecules leads to a decrease in the number of photons that reach the catalyst surface. Because of the influence of many factors and their mutual effects heterogeneous photocatalysis reactions are complicated processes. 


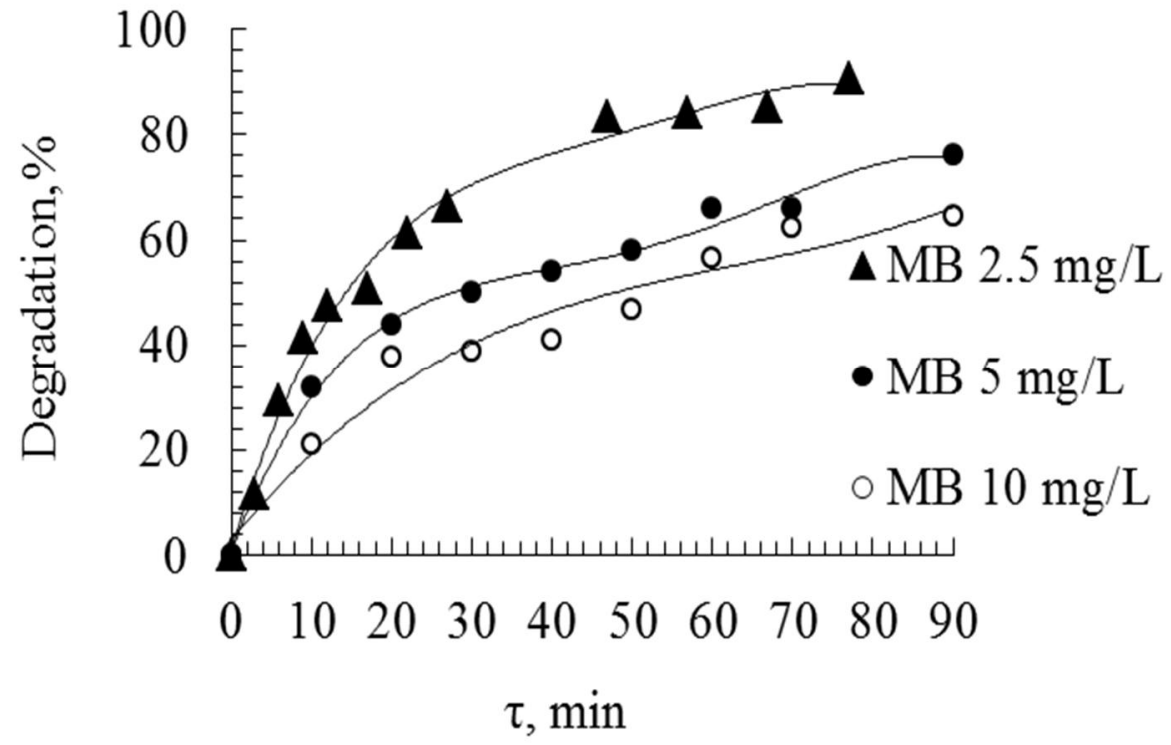

Figure 4. The effect of initial concentration of MB on the photodegradation.

Fig. 5 shows the effect of the catalyst dosage on the dye degradation. The degradation efficiency increases with the increase of the catalyst dosage no so intensive. This enhancement in MB degradation is due to the greater number of active sites available, consequently increasing the number of hydroxyl radicals and superperoxides produced. However, a increase in the catalyst dosage to $7.2 \mathrm{~g} / \mathrm{L}$ lead to a low intensive increase in the degradation of $\mathrm{MB}$, which is caused by the turbidity of the suspension and the lower light penetration due to a higher light scattering effect.

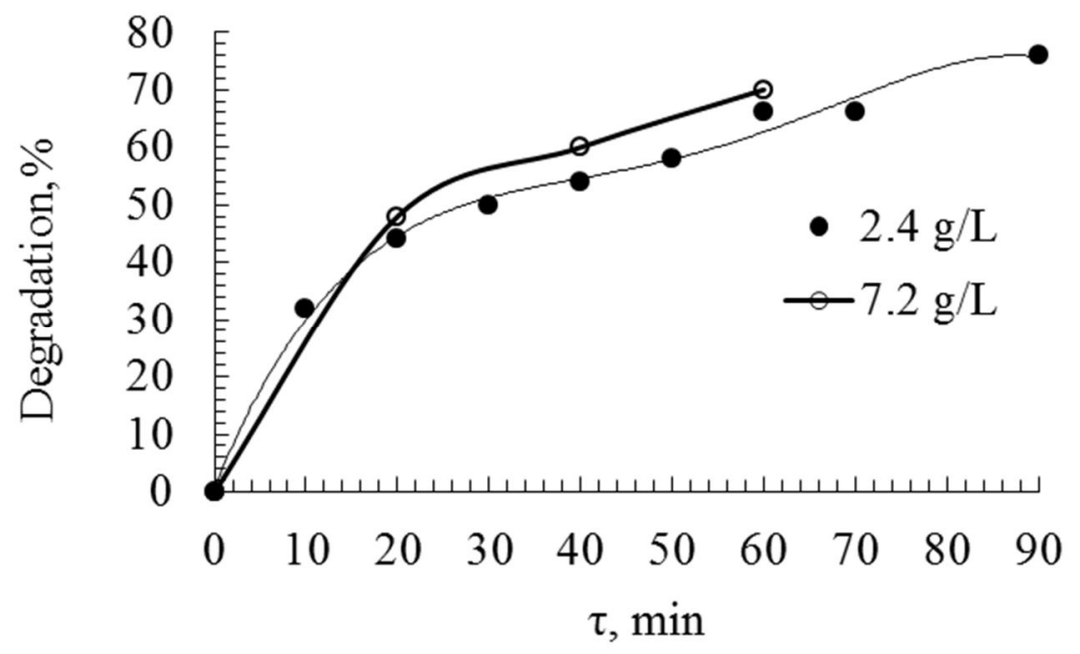

Figure 5. The effect of the catalyst $\mathrm{TiO}_{2} / \mathrm{Ag}$ dosage on the dye degradation. 


\section{Conclusions}

In this study, we used AOP to treat dye solutions and antibiotics which are among the major causes of environmental pollution. a plasma-based AOP was stably generated using contact nonequilibrium low-temperature plasma and plasma synthesized composite nanomaterials $\left(\mathrm{TiO}_{2} / \mathrm{Ag}\right.$ NPs). The decolorization rate of the pollutants was determined by UV-Vis absorption spectroscopy. Experimental results indicated that CNP was effective for degradation azo dye pollutants (methylene blue (MB) and methyl orange MO) and antibiotics (ofloxacin (OFX) and ciprofloxacin (CFX)): $\mathrm{MB}$ and MO were degraded by $98.5 \%$ and $97.0 \%$, respectively; OFX and CFX were degraded by $\sim 95.0 \%$ and $80.0 \%$, respectively AOP by CNP indicated. It has been established that using the optimal operating conditions a phenol degradation equal to $88 \%$ after only 7-10 minutes of treatment was obtained, while the complete degradation and mineralization has been reached after 18-20 minutes. The degradation efficacy of pesticides after $10 \mathrm{~min}$ of plasma treatment were found to be $88.98 \pm 0.91 \%$ for dichlorvos, $72.52 \pm 0.02 \%$ for malathion and $6.78 \pm 0.47 \%$ for endosulfan. It was found, after only 5 minutes of treatment time, the paracetamol degradation was equal to $93-37 \%$. The photodegradation of methylene blue catalyzed by $\mathrm{TiO}_{2} / \mathrm{Ag}$ was studied under UV irradiation. The highest degradation ( 91\%) was obtained with $2.4 \mathrm{~g} / \mathrm{L} \mathrm{TiO} / \mathrm{Ag}$ within 90 min. In future work, we will aim to improve the efficiency of the plasma system by modifying the structure and optimizing the operating conditions.

\section{Conflict of interests}

The authors declare that they have no conflict of interest.

\section{Acknowledgment}

This work was supported by a grant of the Ministry of education and science of Ukraine (grant number 2044, 2019-2021) and program European Union (Harmonising water-related graduate education /WaterH (www.waterh.net).

\section{References}

Attri, P.; Yusupov, M.; Park, J. "Mechanism and comparison of needle-type non-thermal direct and indirect atmospheric pressure plasma jets on the degradation of dyes". Sci Rep., 2016, 6, 34419.

Boretti, A.; Rosa, L. "Reassessing the projections of the world water development report". NPJ. Clean. Water., 2019, 15, 1-6. 
Ceriani, E.; Marotta, E.; Shapoval, V.; Favaro, G.; Paradisi, C. "Complete mineralization of organic pollutants in water by treatment with air non-thermal plasma". Chem. Eng. J., 2018, 337, 567-575. Dontsova, T.; Yanushevska, L.. "Mineral-based magnetic nanocomposite sorbents". Water and water purification technologies. Scientific and technical news, 2020, 26 (1), 27-36.

Foster, J.; Mujovic, S.; Groele, J.; Blankson, M. "Towards high throughput plasma based water purifiers: Design considerations and the pathway towards practical application". J. Phys. D Appl. Phys., 2018, 51, 293001.

Garrido-Cardenas A.; Esteban-Gacia, B. Aguera, A.; Sanchez-Perez, A.; Manzano-Agugilaro, F. "Wastewater treatment by advanced oxidation process and their worldwide research trends". Int. J. Environ. Res. Public. Health., 2020, 17, 170-189.

Ma, S.; Lee, S.; Kim, K.; Im, J.; Jeon, H. "Purification of organic pollutants in cationic thiazine and azo dye solutions using plasma-based advanced oxidation process via submerged multi-hole dielectric barrier discharge". Separation and Purification Technology, 2021. 255, AD117715.

Rancev, S.; Petrovic, M.; Radivojevic, D.; Bojic, A.; Maluckov, C.; Radovic, M. "Prototype of highly efficient liquid electrode pulsating corona plasma reactor for degradation of organics in water", Plasma. Sci. Technol., 2019, 21, 125501.

Tichonovas, M.; Krugly, E.; Racys, V.; Hippler, R.; Kauneliene, V.; Stasiulaitiene, I.; Martuzevicius, D. "Degradation of various textile dyes as wastewater pollutants under dielectric barrier discharge plasma treatment". Chem. Eng. J., 2013, 229, 9-19.

Skiba, M.; Vorobyova, V. "Synthesis of $\mathrm{Ag} / \mathrm{TiO}_{2}$ nanocomposite via plasma liquid interactions and degradation methylene blue". Applied Nanoscience (Switzerland), 2020, 10 (12), 4717-4723.

Sun, B.; Aye, N.; Gao, Z.; Lv, D.; Zhu, X.; Sato, M. "Characteristics of gas-liquid pulsed discharge plasma reactor and dye decoloration efficiency". J. Environ. Sci., 2012, 24, 840-845.

Yehia, S.; Zarif, M.; Bita, B. "Development and Optimization of Single Filament Plasma Jets for Wastewater Decontamination". Plasma Chem Plasma Process, 2020, 40, 1485-1505.

Yamada, M.; Wahyudiono, S. "Nonthermal Atmospheric Pressure Plasma for Methylene Blue Dye Decolorization by Using Slug Flow Reactor System". Plasma Chem Plasma Process, 2020, 40, 985-1000.

Wang, W.; Kim, H.H.; Van Laer, K.; Bogaerts, A. "Streamer propagation in a packed bed plasma reactor for plasma catalysis applications". Chem. Eng. J., 2018, 334, 2467-2479.

Wang, J.L.; Xu, L.J. "Advanced oxidation processes for wastewater treatment: Formation of hydroxyl radical and application". Crit. Rev. Environ. Sci. Technol., 2012, 42, 251-325. 


\title{
ПРОГРЕСИВНИЙ ПРОЦЕС ОКИСЛЕННЯ ЗА ДОПОМОГОЮ ПЛАЗМИ ТА НОВІ МАТЕРІАЛИ ДЛЯ ОЧИЩЕННЯ ВОДИ ТА СТІЧНИХ ВОД
}

\author{
${ }^{1 *}$ М. Скиба, О. Півоваров
}

${ }^{1}$ Кафедра технології неорганічних речовин та екології, Державний вищий навчальний заклад Український державний хіміко-технологічний університет, Дніпро, 49040, Україна.

* Автор для листування: margaritaskiba88@gmail.com

\section{Реферат}

Швидке зростання населення в світі призводить до необхідності вдосконалення сучасних технологій очищення води, щоб забезпечити всіх питною водою належної якості. Прогресивний процеси окислення (AOPs - Advanced Oxidation Processes) на основі низь температурної атмосферної плазми є одним із найбільш широко досліджуваних процесів завдяки своїй екологічності, ефективності та простоті експлуатації. У цьому дослідженні прогресивні процеси окислення із використанням плазмового розряду, що утворено за допомогою контактної нерівноважної низькотемпературної плазми (КНП) та синтезованих плазмохімічним методом наноматеріалів $\left(\mathrm{TiO}_{2} / \mathrm{Ag}_{\text {нч}}\right)$ для очищення води та стічних вод. Ефективність деградації забруднюючих речовин визначали за допомогою спектроскопії. Продемонстровано, що завдяки одночасному утворенню високореакційних окиснювальних сполук у водному розчині плазма може ефективно руйнувати полютанти, які важко зазвичай видалити традиційними методами. Водні розчини різних забруднювачів обробляли розрядом контактної нерівноважної низькотемпературної плазми. Експериментальні результати показали, що КНП є ефективним для деградації забруднювачів азобарвників (метиленовий синій (MC) та метилоранж МО) та антибіотиків (офлоксацин та ципрофлоксацин): МС та МО знебарвлено відповідно на 98,5\% та 97,0\% через 3 хв. обробки розрядом плазми; офлоксацин та ципрофлоксацин було розкладено на 95,0\% та 80,0\%. Також було досліджено фотодеградацію метиленового синього при використанні плазмохімічно одержаного композиту $\mathrm{TiO}_{2} / \mathrm{Ag}_{\text {нч. }}$ Встановлено, що ступінь знебарвлення ( 91\%) була отримана при

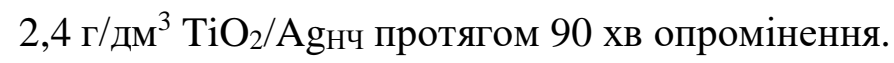

Ключові слова: карбоксиметилцелюлоза, деградачія, барвник, каталітичний, фотокаталітичний, нанокаталізатор, наночастинки срібла. 